\title{
PENGARUH BUDAYA KERJA DAN PROMOSI JABATAN \\ DALAM MENINGKATKAN KINERJA KARYAWAN \\ PADA PT. PERKEBUNAN NUSANTARA III \\ LABUHAN HAJI LABUHANBATU UTARA
}

\author{
Yuniman Zebua \\ Dosen Fakultas Ekonomi dan Bisnis Universitas Labuhanbatu \\ Email : oinitehezeb@gmail.com
}

\begin{abstract}
ABSTRAK
Penelitian ini bertujuan untuk mengetahui pengaruh budaya kerja dan promosi jabatan pada PT. Perkebunan Nusantara III Labuhan Haji Labuhanbatu Utara dalam meningkatkan kinerja karyawan.

PT. Perkebunan Nusantara III Labuhan Haji adalah perusahaan negara yang bergerak dibidang perkebunan. Pengambilkan keputusan masih sulit diterapkan secara objektif karena adanya unsur subjektifitas dalam penilaian seperti faktor sosial dan faktor non sosial. Populasi dalam penelitian ini adalah karyawan PT. Perkebunan Nusantara III Labuhan Haji berjumlah 502 orang. Dengan sampel berjumlah 50 orang. Adapun analisis yang digunakan adalah analisis regresi liniear berganda dengan menggunakan bantuan software SPSS 20.00 for windows.

Hasil penelitian menunjukkan bahwa budaya kerja dan promosi jabatan baik secara parsial (sendirisendiri) maupun secara simultan (s) berpengaruh positif dan signifikan terhadap kepuasan kerja karyawan PT. Perkebunan Nusantara III Labuhan Haji. Hal ini terlihat dari Uji T menunjukkan nilai t-hitung untuk variabel budaya kerja (9.465) dengan nilai sig sebesar 0,000 dan promosi jabatan sebesar (2.583) nilai sig sebesar 0,002, sedangkan untuk nilai t tabel dicari pada tabel t dengan level of test $\alpha=5 \%$ dan df $f_{1}=50$ sehingga diperoleh nilai t tabel sebesar 1.675. Dan dari hasil Uji F menunjukkan bahwa Budaya Kerja dan Promosi Jabatan secara simultan berpengaruh terhadap Peningkatan Kinerja Karyawan bedasarkan kriteria nilai $F_{\text {hitung }}$ sebesar 50.119 dengan nilai signifikan 0,000 . maka $F_{\text {hitung }}(50.119)>F_{\text {tabel }}(3,20)$ dengan signifikasi $0,000^{a}<0,05$.

Dari nilai Asjusted $R$ Square sebesar 0.667 yang berarti bahwa peningkatan kinerja karyawan dapat dijelaskan oleh budaya kerja, promosi jabatan sebesar 66,7\%. Sedangkan sisanya 33,3\% dapat di jelaskan oleh variabel lain yang tidak diteliti dalam penelitian ini.
\end{abstract}

Kata Kunci : Budaya Kerja, Promosi Jabatan, Kinerja Karyawan.

\section{PENDAHULUAN}

Organisasi yang baik, tumbuh dan berkembang akan menitikberatkan pada sumber daya manusia (human resources) guna menjalankan fungsinya dengan optimal, khususnya menghadapi dinamika perubahan lingkungan yang terjadi. Dengan demikian kemampuan teknis, teoritis, konseptual, moral dari para pelaku organisasi/perusahaan di semua tingkat (level) pekerjaan sangat dibutuhkan. Selain itu pula kedudukan sumber daya manusia pada posisi yang paling tinggi berguna untuk mendorong perusahaan menampilkan norma perilaku, nilai dan keyakinan sebagai sarana penting dalam peningkatan kinerjanya.

Karyawan merupakan sumber daya manusia sebagai aset yang sangat vital bagi perusahaan karena kinerja yang mereka lakukan sangat mempengaruhi pertumbuhan perusahaan. Oleh karena itu peningkatan kinerja karyawan menjadi fokus utama unit manajemen sumber daya manusia.

Dalam memahami dan mengimplementasikan budaya kerja pada PT. Perkebunan Nusantara III Labuhan Haji Kabupaten Labuhanbatu Utara merupakan tugas berat yang belum sepenuhnya secara utuh menyeluruh dilaksanakan terutama dalam waktu panjang karena menyangkut proses pembangunan karakter, sikap, dan perilaku serta kebiasaan para karyawan yang belum sepenuhnya 
memiliki kemampuan dan kemauan untuk bekerja secara maksimal.

Kemampuan budaya kerja mempengaruhi kinerja karyawan, karena merupakan kemampuan sumber daya manusia sebagai pendekatan formal yang dilakukan organisasi untuk menjamin orangorang dalam organisasi agar mempunyai kualifikasi dan kemampuan serta pengalaman yang cocok ketika dibutuhkan.

Oleh karena itu, perusahaan perlu mengelola budaya kerja dan mengembangkannya dengan baik supaya produktivitas karyawan tetap terjaga dan mampu mendorong untuk selalu melakukan hal yang terbaik dan menghindari frustasi kerja yang berakibat pada penurunan kinerja perusahaan.

Selain budaya kerja, promosi jabatan juga sangat penting dalam meningkatkan kinerja karyawan. Promosi jabatan karyawan tidak dapat terlepas dari adanya suatu proses pengambilan keputusan, pengambilan keputusan dalam promosi jabatan karyawan tidak bisa dilakukan dengan sembarangan tanpa dukungan informasi dan teknik pengambilan keputusan yang tepat. Kenyataan saat ini, hampir disetiap perusahaan terdapat deviasi antara teori dan praktik pada saat seseorang diputuskan terpilih untuk promosi jabatan.

Seperti halnya yang terjadi di perusahaan PT. Perkebunan Nusantara III Labuhan Haji yang merupakan perusahaan negara yang bergerak dibidang perkebunan. Pengambilan keputusan masih sulit diterapkan secara objektif karena adanya unsur subjektifitas dalam penilaian seperti faktor sosial, dan faktor non sosial.

Faktor sosial disini menunjukan favoritism atau perlindungan terhadap sanak keluarga yang memang bekerja di perusahaan PT. Perkebunan Nusantara III Labuhan Haji. Sebagai perusahaan negara, sebaiknya pengambilan keputusan harus terlebih dahulu melalui mekanisme yang panjang namun hal ini cenderung tidak terjadi. Dalam hal promosi jabatan atasan langsung mengambil keputusan untuk memberikan pekerjaan dan promosi jabatan yang diinginkan. Dalam hal ini juga termasuk unsur perasaan pribadi seorang atasan pada bawahannya "like or dislike" sehingga sering dilakukan tidak sebagaimana seharusnya.

Karyawan memiliki harapan bahwa mereka mendapatkan promosi jabatan ke jabatan atau posisi yang lebih tinggi. Karyawan juga berharap bahwa mereka juga ikut terlibat dalam menentukan keputusan dan kebijakan terkait promosi dan mampu dengan bebas menyampaikan aspirasi mereka tentang keluhan-keluhan yang dirasakan terhadap kebijakan perusahaan secara khusus pada kebijakan promosi jabatan.

Dengan sistem pelaksanaan promosi jabatan yang adil dan merata maka karyawan akan mempunyai anggapan bahwa mereka juga memiliki kesempatan dalam promosi jabatan. Setiap karyawan mengharapkan adanya promosi jabatan karena promosi jabatan mengacu pada adanya kepercayaan dan pengakuan mengenai kemampuan dan kecakapan karyawan dalam bekerja untuk menduduki jabatan yang lebih tinggi.

Promosi jabatan juga diartikan sebagai penghargaan atas keberhasilan karyawan menunjukkan prestasi kerja yang tinggi pada pelaksana tugas-tugas yang dilimpahkan oleh perusahaan kepadanya. Sistem dan perencanaan promosi jabatan pada suatu organisasi akan membuat karyawan menjadi lebih giat bekerja, bersemangat dan berdisiplin sehingga meningkatkan kinerja bagi masing-masing karyawan sehingga tujuan perusahaan dapat tercapai secara optimal.

Karyawan dipacu untuk meningkatkan kualifikasinya agar mampu menempati posisi yang lebih tinggi di perusahaan. Peningkatan kualifikasi sangat penting untuk dilakukan oleh setiap karyawan agar mereka memiliki keunggulan terhadap karyawan lain yang juga menginginkan suatu promosi jabatan. Karyawan akan berupaya untuk meningkatkan kemampuannya agar dapat menjadi kandidat yang layak untuk di promosikan.

Kinerja karyawan diartikan sebagai suatu hasil dan usaha seseorang yang dicapai dengan adanya kemampuan dan perbuatan dalam situasi tertentu. Setiap perusahaan akan berusaha untuk selalu meningkatkan kinerja karyawannya demi tercapainya tujuan yang telah ditetapkan perusahaan. Kinerja seorang karyawan bersifat individual, karena setiap karyawan mempunyai tingkat kemampuan yang berbeda-beda dalam mengerjakan tugasnya.

Kinerja karyawan diarahkan sebagai pengendalian perilaku kerja produktif yang disyaratkan 
untuk mencapai hasil kerja yang disepakati. Penilaian kinerja karyawan dilakukan berdasarkan prinsip objektif, terukur, akuntabel, partisipatif dan transparan.

Pada PT. Perkebunan Nusantara III Labuhan Haji, kinerja karyawan masih terlihat tidak maksimal. Hal ini diakibatkan karena penerapan budaya kerja dan promosi jabatan yang terkesan belum sesuai dengan aturan yang berlaku dan pilih kasih serta pengambilan keputusan masih sulit diterapkan secara objektif karena adanya unsur subjektifitas dalam penilaian seperti faktor sosial dan faktor non sosial.

Berdasarkan uraian di atas, maka dalam penelitian ini peneliti tertarik untuk meneliti mengenai Pengaruh Budaya Kerja dan Promosi Jabatan Dalam Meningkatkan Kinerja Karyawan Pada PT. Perkebunan Nusantara III Labuhan Haji-Labuhanbatu Utara.

\section{RUMUSAN MASALAH}

Berdasarkan pendahuluan di atas, adapun rumusan masalah sebagai berikut :

1. Bagaimana pengaruh Budaya Kerja secara parsial terhadap Peningkatan Kinerja Karyawan Pada PT. Perkebunan Nusantara III Labuhan Haji?

2. Bagaimana pengaruh Promosi Jabatan secara parsial terhadap Peningkatan Kinerja Karyawan Pada PT. Perkebunan Nusantara III Labuhan Haji?

3. Bagaimana pengaruh Budaya Kerja dan Promosi Jabatan secara simultan terhadap Peningkatan Kinerja Karyawan Pada PT. Perkebunan Nusantara III Labuhan Haji?

\section{KERANGKA TEORITIS}

\section{Pengertian Budaya Kerja}

Budaya kerja adalah suatu falsafah dengan didasari pandangan hidup sebagai nilai-nilai yang menjadi sifat, kebiasaan dan juga pendorong yang dibudayakan dalam suatu kelompok serta tercermin dalam sikap menjadi perilaku, cita-cita, pendapat, pandangan dan tindakan yang terwujud sebagai kerja.

Ndraha (2015:101) mendefinisikan budaya kerja, yaitu; "Budaya kerja merupakan sekelompok pikiran dasar atau program mental yang dapat dimanfaatkan untuk meningkatkan efisiensi kerja dan kerjasama manusia yang dimiliki oleh suatu golongan masyarakat. Sedangkan Menurut Osborn (2014:iv) menerangkan bahwa: "Budaya kerja adalah seperangkat perilaku perasaan dan kerangka psikologis yang terinternalisasi sangat mendalam dan dimiliki bersama oleh anggota organisasi.

Nawawi (2016:2) menjelaskan bahwa: budaya kerja adalah kebiasaan yang dilakukan berulang-ulang oleh pegawai dalam suatu organisasi, pelanggaraan terhadap kebiasaan ini memang tidak ada sangsi tegas, namun dari pelaku organisasi secara moral telah menyepakati bahwa kebiasaan tersebut merupakan kebiasaan yang harus ditaati dalam rangka pelaksanaan pekerjaan untuk mencapai tujuan.

Triguno dalam bukunya Manajemen Sumber Daya Manusia (2016:34) menerangkan bahwa: budaya kerja adalah suatu falsafah yang didasari oleh pandangan hidup sebagai nilai-nilai yang menjadi sifat, kebiasaan, dan kekuatan pendorong, membudaya dalam kehidupan suatu kelompok masyarakat atau organisasi yang tercermin dari sikap menjadi perilaku, kepercayaan, cita-cita, pendapat dan tindakan yang terwujud sebagai kerja atau bekerja

Suatu keberhasilan keja berakar pada nilai-nilai yang dimiliki dan perilaku yang menjadi kebiasaan. Nilai-nilai yang menjadi kebiasaan disebut dengan budaya, dikaitkan dengan mutu/kualitas kerja maka dinamakan budaya kerja.

Secara harfiah, pengertian budaya (culture) berasal dari kata Latin 'colere' yang artinya mengerjakan tanah atau mengolah ladang, yang merupakan kebiasaan hidup yang dilakukan orang saat itu. Selanjutnya budaya diartikan sebagai cara hidup tertentu yang memancarkan identitas tertentu pula dari suatu bangsa (Dawson, 2013). 


\section{1) Tujuan Dan Manfaat Budaya Kerja}

a. Tujuan

Untuk merubah sikap dan perilaku sumber daya manusia yang ada dapat meningkatkan produktivitas kerja yang lebih tinggi dalam menghadapi tantangan masa depan.

b. Manfaat dari penerapan budaya kerja yang baik :

- Meningkatkan jiwa gotong royong

- Meningkatkan kebersamaan dan saling terbuka satu sama lain

- Meningkatkan jiwa kekeluargaan

- Meningkatkan rasa kekeluargaan

- Membangun komunikasi yang lebih baik

- Meningkatkan produktivitas kerja

- Tanggap dengan perkembangan dunia luar.

\section{2) Prinsip Budaya Kerja}

Dalam suatu organisasi bekerja melalui serangkaian proses yang saling berkaitan yang terjadi melalui dan melewati batas-batas birokrasi. Kesalahan dalam suatu proses akan mempengaruhi pada kualitas produk akhir ,oleh karena itu jaminan mutu terletak pada kekuatan setiap rangkaian yang berjalan benar sejak pertama pada setiap tahap pekerjaan.

Tujuan fundamental dari budaya kerja adalah untuk membangun sumber daya manusia seutuhnya agar setiap orang sadar bahwa mereka berada dalam suatu hubungan sifat peran, berkomunikasi secara efektif dan efisien yang menggembirakan.

Nilai adalah dasar pertimbangan yang berharga bagi seseorang untuk menentukan sikap dan perilaku dalam menghadapi suatu masalah atau kejadian.

Nilai budaya kerja adalah pilihan nilai-nilai moral dan etika yang dianggap baik dan positif. Nilai tersebut dipedomani secara individu maupun kelompok yang dapat meningkatkan produktivitas dan kinerja dalam pelaksanaan tugas penyelenggaraan pemerintahan, pembangunan dan pelayanan masyarakat.

Setiap manusia harus mau menghadapi perubahan, terutama dalam program Budaya Kerja , masalah perubahan dalam program budaya kerja musuh terberat adalah diri kita sendiri, oleh karena itu kita harus memiliki komitmen yang kuat untuk melakukan perubahan.

Perubahan merupakan hal yang penting dalam program budaya kerja, karena masalah budaya kerja adalah masalah perilaku kita sendiri. Karena itu dalam membangun budaya kerja kita harus berkomitmen untuk melakukan perubahan pada diri kita berdasar pada empat potensi dasar manusia yaitu :

a. Kesadaran diri : mampu mengambil jarak terhadap diri sendiri dan menelaah pemikiran kita sendiri, tindakan, kebiasaan, memungkinkan kita mennjadi sadar akan nilai-nilai social psikhis dari program yang ada dalam diri kita untuk mencari peluang antara rangsangan dan tanggapan.

b. Hati nurani: mampu menghubungkan kita dengan perkembangan jaman,merupakan alat pemberi arah dalam hati kita untuk memehami bila bertindak atau merenungkan sesuatu yang tidak sejalan.

c. Kehendak bebas memberikan kemampuan untuk memberikan kekeuatan mengatasi paradigmparadigma kita utk melawan arus, memiliki kekuatan utk bertindak berdasarkan hati nurani dan visi.

d. Imajinasi kreatif merupakaan kemampuan untuk melihat kemasa yang akan datang untuk menciptakan sesuatu sesuai dengan prinsip organisasi .

Budaya kerja merupakan suatu komitmen yang luas dalam upaya untuk membangun sumber daya manusia, proses kerja dan hasil kerja yang lebih baik, hal ini bersumber dari pribadi masingmasing individu yang terkait dalam organisasi kerja itu sendiri.

\section{3) Penerapan Budaya Kerja}


1. Penanggung Jawab. Bertanggung jawab akan keberhasilan pelaksanaan program komitmen.

2. Tim Pengarah. Memberikan pengarahan pada fasilitataor / Kelompok Budaya Kerja (KBK) agar berjalan sesuai dengan program.

3. Fasilitator. Menyebarluaskan Budaya Kerja, membimbing KBK dan melaporkan kegiatan KBK kepada Tim Pengarah.

4. Ketua Kelompok. Memimpin jalannya rapat KBK, member motivasi anggota dan melaporkan kegiatan KBK kepada Tim Pengarah

5. Anggota KBK. Partisipasi dalam KBK dan Belajar terus agar mampu memecahkan masalah.

\section{4) Dimensi dan Indikator Budaya Kerja}

Menurut Robbins dalam Ichsan Nugraha (2016), dimensi dan indikator budaya kerja adalah:

1. Inovasi dan mengambil resiko

a. Dukungan dan suasana kerja terhadap kreatifitas

b. Penghargaan terhadap aspirasi karyawan perusahaan

c. Pertimbangan karyawan perusahaan dalam mengambil resiko

d. Tanggung jawab karyawan perusahaan.

2. Perhatian pada rincian

a. Ketelitian dalam melakukan pekerjaan

b. Evaluasi hasil kerja

3. Orientasi hasil

a. Pencapaian target

b. Dukungan lembaga dalam bentuk fasilitas kerja

4. Orientasi manusia

a. Perhatian perusahaan terhadap kenyamanan kerja

b. Perhatian perusahaan terhadap rekreasi

c. Perhatian perusahaan terhadap keperluan

pribadi

5. Orientasi tim

a. Kerja sama yang terjadi antara karyawan perusahaan

b. Toleransi antar karyawan perusahaan

6. Agresifitas

a. Kebebasan untuk memberikan kritik

b. Iklim bersaing dalam perusahaan

c. Kemauan karyawan untuk meningkatkan kemampuan diri

7. Stabilitas yaitu Kemantapan atau mempertahankan status dalam organisasi Gambaran tersebut menjadi basis bagi pemahaman bersama yang dimiliki para anggota mengenai organisasi, dan bagaimana segala sesuatu dilakukan didalamnya sesuai dengan apa yang telah ditentukan atau disepakati bersama.

\section{Pengertian Promosi Jabatan}

Menurut Siagian (2012:20) : "Promosi jabatan adalah perpindahan pegawai dari satu pekerjaan ke pekerjaan lain yang tanggung jawabnya lebih besar, tingkatan hirarki jabatannya lebih tinggi dan penghasilannya pun lebih besar pula."

Menurut Hasibuan (2012:73) : "Promosi jabatan berarti perpindahan yang memperbesar wewenang dan tanggung jawab ke jabatan yang lebih tinggi di dalam suatu organisasi yang diikuti dengan kewajiban, hak, status, dan penghasilan yang lebih besar."

Pendapat serupa juga diungkapkan oleh ahli ilmu manajemen yaitu Flipo (2014:26) yang menyatakan bahwa promosi jabatan adalah perpindahan dari suatu jabatan ke jabatan lainnya yang 
mempunyai status dan tanggung jawab yang lebih tinggi. Biasanya perpindahan ke jabatan yang lebih tinggi disertai dengan peningkatan gaji/upah lainnya, walaupun tidak selalu demikian.

\section{a. Tujuan Promosi Jabatan}

Menurut Hasibuan (2014) tujuan promosi jabatan adalah sebagai berikut :

1) Untuk memberikan pengakuan, jabatan dan imbalan jasa yang semakin besar kepada karyawan berprestasi kerja tinggi.

2) Dapat menimbulkan kepuasan dan kebanggaan pribadi, status sosial, yang semakin tinggi dan penghasilan yang semakin besar.

3) Untuk merangsang agar karyawan lebih bergairah dalam bekerja, berdisiplin tinggi dan memperbesar produktivitas kerjanya.

4) Untuk menjamin stabilitas kepegawaian dengan direalisasikannya promosi jabatan jabatan kepada karyawan dengan dasar dan waktu yang tepat serta penilaian jujur.

5) Memberikan kesempatan kepada karyawan untuk mengembangkan kreativitas dan inovasinya yang lebih baik demi keuntungan optimal perusahaan.

6) Untuk menambah atau memperluas pengetahuan serta pengalaman kerja para karyawan dan ini merupakan daya dorong bagi karyawan lainnya.

7) Untuk mengisi kekosongan jabatan karena pejabatnya berhenti.

8) Agar jabatan tersebut tidak lowong maka dipromosikan karyawan lainnya.

9) Karyawan yang dipromosikan kepada jabatan yang tepat, semangat, kesenangan dan ketenangannya dalam bekerja akan semakin meningkat sehingga produktifitas kerjanya juga akan meningkat.

10) Untuk mempermudah penarikan pelamar, sebab dengan adanya kesempatan promosi jabatan merupakan daya dorong serta perangsang bagi para pelamar-pelamar untuk memasukkan lamaran kerjanya.

\section{b. Dasar-dasar Pertimbangan Promosi Jabatan}

Program promosi jabatan hendaknya memberikan informasi yang jelas, apa yang dijadikan dasar pertimbangan untuk mempromosikan seorang karyawan dalam perusahaan tersebut. Pedoman yang dijadikan dasar untuk untuk mempromosikan karyawan menurut Hasibuan (2014:110) meliputi :

1. Pengalaman, pengalaman yaitu promosi jabatan yang didasarkan pada lamanya pengalaman kerja karyawan. Pertimbangan promosi jabatan adalah pengalaman kerja seseorang, orang yang telah lama bekerja dalam perusahaan mendapat prioritas pertama dalam tindakan promosi jabatan. Kebaikannya adalah adanya penghargaan dan pengakuan bahwa pengalaman merupakan saka guru yang berharga. Dengan pengalaman, seseorang akan dapat mengembangkan kemampuannya sehingga karyawan tetap betah bekerja pada perusahaan dengan harapan suatu waktu ia akan dipromosikan. Kelemahannya adalah seorang karyawan yang kemampuannya sangat terbatas, tetapi karena sudah lama bekerja tetap dipromosikan. Dengan demikian, perusahaan akan dipimpin oleh seorang yang berkemampuan rendah, sehingga perkembangan dan kelangsungan perusahaan disangsikan.

2. Kecakapan (Ability) Kecakapan berarti seseorang akan dipromosikan berdasarkan penilaian kecakapan. Pertimbangan promosi jabatan adalah kecakapan, orang yang cakap atau ahli mendapat prioritas utama untuk dipromosikan. Kecakapan adalah total dari semua keahlian yang diperlukan untuk mencapai hasil yang bisa dipertanggung jawabkan. Kecakapan merupakan kumpulan pengetahuan yang diperlukan untuk memenuhi hal-hal berikut:

3. Kecakapan dalam pelaksanaan prosedur kerja yang praktis, teknik-teknik khusus dan disiplin ilmu pengetahuan.

4. Kecakapan dalam menyelaraskan dan meyatukan bermacam- macam elemen yang semuanya terlibat di dalam penuyusunan kebijaksanaan dan dalam situasi manajemen. Kecakapan di bidang ini bisa digunakan untuk pekerjaan konsultasi atau pekerjaan pelaksanaan. Kecakapan ini mengkombinasikan elemen-elemen dari perencanaan, pengorganisasian, pengaturan (directing), penilaian (evaluating), dan pembaruan (innovating) 
5. Kecakapan dalam memberikan motivasi secara langsung. Kesulitan mengukur kecakapan adalah menentukan tolak ukur kecakapan. Apakah nilai ijazah dipakai sebagai bahan pertimbangan untuk mengukur kemampuan seseorang sedangkan nilai ijazah hana mencerminkan kecerdasan seseorang pada saat ujian saja.

6. Kombinasi pengalaman dan kecakapan. Kombinasi pengalaman dan kecakapan yaitu promosi jabatan yang berdasarkan pada lamanya pengalaman dan kecakapan. Pertimbangan promosinya adalah berdasarkan lamanya dinas, ijazah pendidikan formal yang dimiliki dan hasil ujian kenaikan golongan.

Cara ini adalah dasar promosi jabatan yang terbaik dan paling tepat karena mempromosikan orang yang paling berpengalaman dan terpintar, sehingga kelemahan promosi jabatan jabatan yang hanya berdasarkan pengalaman atau kecakapan saja dapat diatasi. Promosi jabatan yang berdasarkan kombinasi pengalaman dan kecakapan juga mempunyai beberapa kelebihan dan kelemahan, yaitu :

\section{Kelebihan :}

1) Memotivasi karyawan untuk memperdalam pengetahuannya bahkan memaksa diri mengikuti pendidikan formal. Dengan demikian, perusahaan akan mempunyai karyawan yang semakin terampil.

2) Moral karyawan akan semakin baik, bergairah, semangat dan prestasi kerjanya semakin meningkat karena ini termasuk elemen-elemen yang dinilai untuk promosi jabatan.

3) Disiplin karyawan semakin baik karena disiplin termasuk elemen yang akan mendapat penilaian prestasi untuk dipromosikan.

4) Memotivasi berkembangnya persaingan sehat dan dinamis di antara para karyawan sehingga mereka berlomba-berlomba untuk mencapai kemajuan.

5) Perusahaan akan menempatkan karyawan yang terbaik pada setiap jabatan sehingga sasaran optimal akan tercapai.

Kelemahan :

1) Karyawan yang kurang mampu akan frustasi bahkan mengundurkan diri dari perusahaan itu.

2) Biaya perusahaan akan semakin besar karena adanya ujian kenaikan golongan.

\section{c. Syarat-syarat Promosi Jabatan}

Dalam mempromosikan karyawan, perusahaan harus mempuyai syarat-syarat tertentu yang telah direncanakan sebelumnya. Syarat-syarat promosi jabatan harus diinformasikan kepada semua karyawan, agar mereka mengetahui secara jelas. Syarat-syarat promosi jabatan menurut Hasibuan (2014:122) meliputi hal-hal berikut :

1) Mempunyai kejujuran yang tinggi

Karyawan harus jujur pada dirinya sendiri, bawahannya, perjanjian-perjanjian dalam melaksanakan atau mengelola jabatan tersebut, harus sesuai kata dengan perbuatannya. Dia tidak menyelewengkan jabatannya untuk kepentingan pribadinya.

2) Mempunyai disiplin kerja yang baik

Karyawan harus disiplin pada dirinya, tugas-tugasnya serta mentaati peraturan yang berlaku baik secara lisan maupun tertulis maupun kebiasaan. Disiplin karyawan sangat penting karena hanya dengan kedisiplinan memungkinkan perusahaan dapat mencapai hasil yang optimal.

3) Memiliki prestasi kerja yang baik

Karyawan mampu mencapai hasil kerja yang baik dan dapat dipertanggungjawabkan kualitas maupun kuantitasnya serta bekerja secara efektif dan efisien. Hal ini menunjukkan bahwa karyawan dapat memanfaatkan waktu dan mempergunakan alat-alat dengan baik.

4) Mampu bekerjasama

Karyawan dapat bekerja sama secara harmonis dengan sesama karyawan baik horizontal maupun vertikal dalam mencapai sasaran perusahaan. Dengan demikian akan tercipta suasana hubungan kerja yang baik semua karyawan

5) Kecakapan 
Karyawan harus cakap, kreatif, dan inovatif dalam menyelesaikan tugas-tugasnya pada jabatan tersebut. Bekerja secara madiri dalam menyelesaikan pekerjaannya dengan baik, tanpa mendapatkan bimbingan yang terus menerus dari atasannya.

6) Loyalitas tehadap perusahaan

Karyawan harus loyal dalam membela perusahaan dari tindakan yang dapat merugikan perusahaan. Ini menunjukkan bahwa adanya partisipasi aktif karyawan terhadap perusahaan.

7) Mempunyai jiwa kepemimpinan

Karyawan harus mampu membina dan memotivasi bawahannya untuk bekerjasama dan bekerja secara efektif dalam mencapai sasaran perusahaan. Dia harus menjadi panutan dari para bawahannya.

8) Komunikatif

Karyawan harus mampu berkomunikasi secara efektif dan mampu menerima atau mempersepsikan informasi dari atasan dengan baik, sehingga tidak terjadi kesalahpahaman.

9) Pendidikan yang sesuai dengan jabatan

Karyawan harus memiliki ijazah dari pendidikan formal sesuai dengan spesifikasi jabatannya.

\section{Pengertian Kinerja Karyawan}

Menurut Nitisemo (2014) mendefinisikan kinerja (performance) sebagai hasil kerja yang dapat dicapai oleh seseorang atau kelompok orang dalam suatu organisasi sesuai wewenang dan tanggungjawab masing-masing, dalam rangka mencapai tujuan organisasi yang bersangkutan. Dengan kata lain, kinerja perorangan dan kinerja kelompok sangat mempengaruhi kinerja perusahaan atau organisasi secara keseluruhan dalam rangka mencapai tujuan perusahaan tersebut.

Hasibuan (2012) menyatakan bahwa secara sederhana kinerja adalah apa yang dikerjakan atau tidak dikerjakan oleh karyawan. Kinerja adalah suatu hasil kerja yang dicapai seseorang dalam melaksanakan tugas-tugas yang dibebankan kepadanya yang didasarkan atas kecakapan, pengalaman, dan kesungguhan serta waktu. Kinerja ini adalah gabungan dari tiga faktor penting, yaitu kemampuan dan minat seseorang pekerja, kemampuan dan penerimaan atas penjelasan delegasi tugas dan peran, serta tingkat motivasi seoran pekerja. Semakin tinggi ketiga faktor di atas maka semakin besar kinerja pegawai yang bersangkutan.

Sedangkan menurut Sedarmayati (2014), kegiatan yang paling lazim dinilai dalam organisasi adalah kinerja seseorang, yaitu bagaimana ia melakukan segala sesuatu yang berhubungan dengan suatu jabatan, pekerjaan, atau peranan dalam organisasi. Kinerja merupakan kondisi yang harus diketahui dan diinformasikan kepada pihak-pihak tertentu untuk mengetahui tingkat pencapaian hasil suatu instansi dihubungkan dengan visi yang diemban suatu organisasi serta mengetahui dampak positif dan negatif suatu kebijakan operasional yang diambil.

Berdasarkan pengertian-pengertian yang dikemukakan oleh para ahli, maka dapat disimpulkan bahwa kinerja merupakan perbandingan hasil kerja yang dicapai oleh pegawai dengan standar yang telah ditentukan. Kinerja juga berarti hasil yang dicapai oleh seseorang, baik kualitas maupun kuantitas dalam suatu organisasi sesuai dengan tanggung jawab yang diberikan.

\section{a. Penilaian Kinerja}

Penilaian kinerja adalah kegiatan manajer untuk mengevaluasi perilaku dan kinerja karyawan serta menetapkan kebijaksanaan selanjutnya. Penialaian perilaku yaitu menilai kesetiaan, kejujuran, kepemimpinan, kerjasama, loyalitas dedikasi dan partisipasi pegawai. Menilai perilaku ini sulit karena tidak ada standar fisiknya, sedangkan untuk penilaian hasil kerja relatif lebih mudah karena ada standar fisik yang dapat dipakai sebagai tolak ukurnya, seperti satuan meter, liter dan sebagainya.

Menurut Paryaman (2014) dalam kehidupan suatu organisasi, ada beberapa asumsi tentang perilaku manusia sebagai sumber daya manusia yang mendasari pentingnya penilaian kinerja pegawai dan asumsi tersebut antara lain :

1) Setiap orang ingin memiliki peluang untuk mengembangkan kemampuan kinerjanya sampai tingkat maksimal. 
2) Setiap orang ingin mendapatkan penghargaan apabila ia dinilai melaksanakan tugasnya dengan baik.

3) Setiap orang ingin mengetahui secara pasti tentang karier yang akan diraihnya apabila dapat melaksanakan tugasnya dengan baik.

4) Setiap orang ingin mendapatkan perlakuan yang objektif dan penilaian atas dasar kinerja.

5) Setiap orang pada umunya tidak hanya melakukan kegiatan yang sifatnya rutin.

\section{b. Pengukuran Kinerja}

Keberhasilan ataupun kegagalan kinerja suatu organisasi, dapat di ukur dengan dilakukannya suatu pengukuran dan suatu pelaporan hasilhasil kerja dari para aparatur, yang dilakukan secara formal, menurut Veithzal Rivai dalam bukunya Performance Appraisal menyatakan laporan hasil pengukuran kinerja mempunyai dua fungsi:

1. Sebagai pertanggungjawaban atas hasil yang dicapai, proses yang dilakukan, dan sumber daya yang telah dipercaya untuk dikelola.

2. Sebagai umpan balik dalam rangka meningkatkan kinerja di masa yang akan datang. (Rivai 2011)

\section{c. Indikator kinerja}

Mc. Donald dan Lawton dalam Ratminto dan Atik Septi Winarsih (2005) mengemukakan indikator kinerja antara lain : output oriented measures throughput, efficiency, effectiveness. Selanjutnya indikator tersebut dijelaskan sebagai berikut:

a. Efficiency atau efisiensi adalah suatu keadaan yang menunjukkan tercapainya perbandingan terbaik antara masukan dan keluaran dalam penyelenggaraan pelayanan publik.

b. Effectiveness atau efektivitas adalah tercapainya tujuan yang telah ditetapkan, baik dalam bentuk target, sasaran jangka panjang maupun misi organsiasi.

Salim dan Woodward dalam Ratminto dan Atik Septi Winarsih (2005), mengemukakan idikator kinerja antar lain: economy, efficiency, effectiveness, equity. Secara lebih lanjut, indikator tersebut diuraikan sebagai berikut :

a. economy atau ekonomis adalah penggunaan sumber daya sesedikit mungkin dalam proses penyelenggaraan pelayanan publik.

b. Efficiency atau efisiensi adalah suatu keadaan yang menunjukkan tercapainya perbandingan terbaik antara masukan dan keluaran dalam penyelenggaraan pelayanan publik.

c. Effectiveness atau efektivitas adalah tercapainya tujuan yang telah ditetapkan, baik itu dalam bentuk target, sasaran jangka panjang maupun misi organisasi.

d. Equity atau keadilan adalah pelayanan publik yang diselenggarakan dengan memperhatikan aspek-aspek kemerataan.

Lenvinne dalam Ratminto dan Atik Septi Winarsih (2005) mengemukakan indikator kinerja terdiri dari : responsiveness, responsibility, accountability.

a. Responsiveness atau responsivitas ini mengukur daya tanggap provider terhadap harapan, keinginan, aspirasi serta tuntutan customers.

b. Responsibility atau responsibilitas adalah suatu ukuran yang menunjukkan seberapa jauh proses pemberian pelayanan publik dilakukan dengan tidak melanggar ketentuan-ketentuan yang telah ditetapkan.

c. Accountability atau akuntabilitas adalah suatu ukuran yang menunjukkan seberapa besar tingkat kesesuaian antara penyelenggaraan pelayanan dengan ukuran-ukuran eksternal yang ada di masyarakat dan dimiliki oleh stake holders, seperti nilai dan norma yang berkembang dalam masyarakat.

Zeithaml, Parasuraman dan Berry dalam Ratminto dan Atik Septi Winarsih (2005) menjelaskan tentang indikator yang digunakan untuk menilai kinerja organisasi, yang terdiri atas beberapa faktor berikut :

a. Tangibles atau ketampakan fisik, artinya ketampakan fisik dari gedung, peralatan, pegawai, dan fasilitasfasilitas lain yang dimiliki oleh providers. 
b. Reliability atau reabilitas adalah kemampuan untuk menyelenggarakan pelayanan yang dijanjikan secara akurat.

c. Responsiveness atau responsivitas adalah kerelaan untuk menolong customers dan menyelenggarakan pelayanan secara ikhlas.

d. Assurance atau kepastian adalah pengetahuan dan kesopanan para pekerja dan kemampuan mereka dalam memberikan kepercayaan kepada customers.

Emphaty adalah perlakuan atau perhatian pribadi yang diberikan oleh providers kepada customers.

\section{d. Faktor yang Mempengaruhi Kinerja}

Kinerja dipengaruhi oleh berbagai faktor baik yang berhubungan dengan tenaga kerja itu sendiri, maupun yang berhubungan dengan lingkungan perusahaan, masyarakat dan pemerintah secara keseluruhan. Hal tersebut didasarkan atas pernyataan Nawawi (2015) yang membuktikan bahwa kinerja merupakan hasil kerja yang dicapai seseorang dalam melasanakan tugas-tugas yang dibebankan kepadanya, berdasarkan kecakapan (pengetahuan, ketrampilan/keahlian), pengalaman kerja, dan kepribadian (motivasi, minat, disiplin, kemampuan bekerja sama).

Selain itu, Mangkunegara (2012) juga menjelaskan bahwa pencapaian kinerka dipengaruhi oleh faktor kemampuan dan faktor motivasi. Menurut Gibson (2013) banyak faktor yang mempengaruhi kinerja seorang pegawai, diantaranya yaitu :

a) Variabel Individu

Kemampuan dan ketrampilan merupakan variable individual yang dapat mempengaruhi kinerja seorang pegawai, karena kemampuan merupakan potensial seorang untuk menyelesaikan suatu pekrjaan sekaligus sebagai hasil dari pengetahuan dan ketrampilan seorang yang dipengaruhi oleh tingkat pendidikan, latihan, dan pengembangan dalam hubungannya dengan tugas yang dimiliki.

b) Variabel Organisasional

Variable organisasional terdiri dari sumber daya manusia, kepemimpinan, dan system upah atau pendapatan. Manusia dalah sumber daya yang berharga bagi perusahaan, karena melalui kegiatan-kegiatan manusia tujuan perusahaan dapat tercapai. Sehingga dapat dikatakan bahwa keberhasilan suatu perusahaan tergantung pada unsur manusia yang ada didalamnya.

c) Variabel Psikologis

Pemupukan motivasi dan minat kerja pegawai yang berorientasi pada peningkatan prestasi atau hasil kerja, membutuhkan waktu yang lama dan memerlukan teknik-teknik tertentu, antara lain dengan meciptakan iklim dan lingkungan kerja yang kondusif. Sikap merupakan salah satu penentu perilaku pegawai dalam bekerja.

Kemampuan sumber daya manusia merupakan pendekatan formal yang dilakukan organisasi untuk menjamin orang-orang dalam organisasi mempunyai kualifikasi dan kemampuan serta pengalaman yang cocok ketika dibutuhkan. Oleh karena itu, perusahaan perlu mengelola karir dan mengembangkannya dengan baik supaya produktivitas pegawai tetap terjaga dan mampu mendorong pegawai untuk selalu melakukan hal yang terbaik dan menghindari frustasi kerja yang berakibat penurunan kinerja perusahaan.

Sumber daya manusia merupakan modal, karena mereka sebagai motor penggerak maju mundurnya perusahaan. Pemberdayaan pegawai secara efektif dan efisien diperlukan demi pencapaian tujuan perusahaan. Budaya kerja adalah sarana untuk mencapai tujuan perusahaan, sehingga dengan budaya kerja dapat memacu kinerja pegawai untuk dapat mencapai tujuan perusahaan. Sehingga dengan tercapainya tujuan perusahaan maka pegawai juga akan merasakan keberhasilan mereka dalam bekerja dan tentunya perusahaan juga akan memberikan tambahan balas jasa kepada para pegawaiya.

\section{HIPOTESIS PENELITIAN}

Kerangka pemikiran dan hasil kajian empiris peneliti mengajukan beberapa hipotesis dalam penelitian ini sebagai berikut : 
$\mathrm{H}_{1}$ : Diduga secara Parsial Budaya Kerja berpengaruh terhadap Peningkatan Kinerja Karyawan PT. Perkebunan Nusantara III Labuhan Haji.

$\mathrm{H}_{2}$ : Diduga secara Parsial Promosi Jabatan berpengaruh terhadap Peningkatan Kinerja Karyawan PT. Perkebunan Nusantara III Labuhan Haji.

$\mathrm{H}_{3}$ : Diduga secara Simultan Budaya Kerja dan Promosi Jabatan berpengaruh terhadap peningkatan Kinerja Karyawan PT. Perkebunan Nusantara III Labuhan Haji.

\section{METODOLOGI PENELITIAN}

Penelitian ini dilakukan pada PT. Perkebunan Nusantara III Labuhan Haji Kabupaten Labuhanbatu Utara.

Populasi dalam penelitian ini adalah seluruh karyawan PT. Perkebunan Nusantara III Labuhan Haji sebanyak 502 orang. Sedangkan sampel diambil secara acak sebanyak 50 orang berdasarkan Arikunto, (2014:41) yang menyatakan bahwa jika populasi lebih dari 100 orang, maka sebaiknya diambil antara 10-40\% dari jumlah populasi tersebut. Maka dengan demikian penetapan sampel sebesar $10 \%$ dari jumlah populasi.

Adapun jenis data yang digunakan dalam penelitian ini adalah :

1. Data kuantitatif, yaitu data yang dapat dihitung berupa angka-angka yang diperoleh dari bukubuku, laporan-laporan yang berasal dari PT. Perkebunan Nusantara III Labuhan Haji.

2. Data kualitatif, yaitu data yang diperoleh dari perusahaan dalam bentuk informasi baik secara lisan maupun tulisan, yang berperan sebagai pendukung bagi data yang dibutuhkan, misalnya sejarah berdirinya perusahaan, struktur organisasi, serta data lainnya yang menunjang pembahasan.

Berdasarkan sumbernya, data penelitian dapat dikelompokkan dalam dua jenis yaitu data primer dan data sekunder. Data primer adalah data yang diperoleh atau dikumpulkan oleh peneliti secara langsung dari sumber datanya. Data sekunder adalah data yang diperoleh atau dikumpulkan peneliti melalui studi pustaka serta dari berbagai sumber seperti buku, jurnal, internet dan sebagainya.

Teknik pengumpulan data dilakukan secara observasi, wawancara dan kuesioner. Sedangkan teknik analisis data yang digunakan pada penelitian ini adalah analisis regresi linier berganda. Analisis regresi liniear berganda digunakan untuk mengetahui pengaruh variabel bebas (X) yang lebih dari 2 (dua) variabel terhadap variabel terikat (Y). Pengolahan data dilakukan dengan menggunakan bantuan software SPSS 20.00 for windows. Analisis regresi berganda menggunakan persamaan, sebagai berikut:

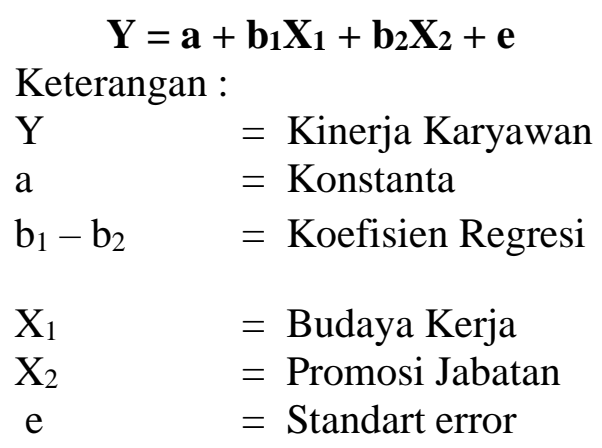

\section{Uji Hipotesis}

Setelah persamaan regresi didapat, maka tahap berikutnya adalah melakukan pengujian terhadap hipotesis penelitian untuk mengetahui apakah variabel budaya kerja, promosi jabatan, dapat digunakan untuk memprediksi variabel kinerja karyawan.

Pengujian hipotesis tersebut dilakukan dengan uji statistik yaitu : 
a. Uji Parsial (Uji t)

Uji statistik pada dasarnya menunjukkan seberapa jauh pengaruh variabel budaya kerja, promosi jabatan, dapat digunakan untuk memprediksi variabel kinerja karyawan.

Kriteria pengujiannya sebagai berikut:

Jika probabilitas (signifikansi) lebih besar dari $0,05(\alpha)$, maka variabel independen secara individual tidak berpengaruh terhadap variabel dependen.

Jika probabilitas (signifikansi) lebih kecil dari $0,05(\alpha)$, maka variabel independen secara individual berpengaruh terhadap variabel dependen. Kriteria pengujian :

Ho, diterima dan Ha ditolak jika t hitung kurang dari t tabel. Artinya variabel independen tersebut tidak berpengaruh secara signifikan terhadap variabel dependen.

Ho, ditolak dan Ha diterima jika t hitung lebih besar dari t tabel. Artinya variabel independen tersebut berpengaruh secara signifikasi terhadap variabel dependen.

b. Uji Simultan (Uji F)

Uji statistik $\mathrm{F}$ pada dasarnya menunjukkan apakah semua variabel independen promosi jabatan $\left(\mathrm{X}_{1}\right)$, kompensasi $\left(\mathrm{X}_{2}\right)$, dapat digunakan untuk memprediksi variabel kepuasan kerja (Y).

Kriteria pengujian :

Jika tingkat signifikansi $\mathrm{F}>0,05$ atau $\mathrm{F}$ hitung $<\mathrm{F}$ tabel, maka Ho diterima.

Jika tingkat signifikansi $\mathrm{F}<0,05$ atau $\mathrm{F}$ hitung $>\mathrm{F}$ tabel, maka Ho ditolak.

\section{HASIL PENELITIAN DAN PEMBAHASAN}

\section{HASIL PENELITIAN}

\section{Hasil Persamaan Analisis Regresi Linier Berganda}

Tabel 1

Hasil Persamaan Analisis Regresi Linier Berganda

Model persamaan regresi berganda dapat dilihat dibawah ini:

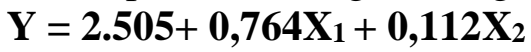

\section{Keterangan :}

a) Koefisien regresi konstanta sebesar 2.505 menunjukkan bahwa vaiabel budaya kerja dan promosi jabatan konstan, maka kinerja karyawan bernilai sebesar 2.505.

b) Koefisien regresi budaya kerja sebesar 0,764 mempunyai arti bahwa variabel budaya kerja mengalami kenaikkan sebesar satu satuan, maka kinerja karyawan mengalami peningkatan sebesar 0,764.

c) Koefisien regresi promosi jabatan sebesar 0,112 mempunyai arti bahwa variabel promosi jabatan mengalami kenaikkan sebesar satu satuan, maka kinerja karyawan mengalami peningkatan sebesar 0,112 .

\section{Hasil Pengujian Hipotesis}

\section{Uji Parsial (Uji T)}

Uji Parsial (Uji T) dilakukan untuk menguji apakah budaya kerja dan promosi jabatan secara individu atau sendidi-sendiri berpengaruh terhadap kinerja karyawan PT. Perkebunan Nusantara III

Coefficients $^{\mathrm{a}}$

\begin{tabular}{|c|c|c|c|c|c|}
\hline \multirow[t]{2}{*}{ Model } & \multicolumn{2}{|c|}{$\begin{array}{l}\text { Unstandardized } \\
\text { Coefficients }\end{array}$} & \multirow{2}{*}{$\begin{array}{c}\begin{array}{c}\text { Standardiz } \\
\text { ed } \\
\text { Coefficien } \\
\text { ts }\end{array} \\
\text { Beta }\end{array}$} & \multirow[t]{2}{*}{$\mathrm{T}$} & \multirow[t]{2}{*}{ Sig. } \\
\hline & B & $\begin{array}{l}\text { Std. } \\
\text { Error }\end{array}$ & & & \\
\hline (Constant) & 2.505 & 1.873 & & 1.337 & .188 \\
\hline 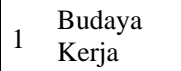 & .764 & .081 & .792 & 9.465 & .000 \\
\hline $\begin{array}{l}\text { Promosi } \\
\text { Jabatan }\end{array}$ & .112 & .071 & .132 & 2.583 & .002 \\
\hline
\end{tabular}

a. Dependent Variable: Kinerja Karyawan 
Labuhan Haji Kabupaten Labuhanbatu Utara, dapat dilihat pada Tabel 2 berikut :

Tabel 2

Hasil Uji Parsial (Uji T)

Tabel 2, menunjukkan nilai t-hitung untuk variabel budaya kerja $(9,465)$ dengan nilai sig sebesar 0,000 dan promosi jabatan sebesar $(2,583)$ nilai sig sebesar 0,002 , sedangkan untuk nilai t tabel dicari pada tabel $\mathrm{t}$ dengan level of test $\alpha=5 \%$ dan $\mathrm{df}_{1}=50$ sehingga diperoleh nilai $\mathrm{t}$ tabel sebesar 1.675

Maka $t_{\text {hitung }}>t_{\text {tabel }}(9,465>1,675)$ secara parsial variabel budaya kerja berpengaruh positif dan signifikan terhadap kinerja karyawan PT. Perkebunan Nusantara III Labuhan Haji dan $\mathrm{t}$ hitung $<\mathrm{t}$ tabel $(2,583>1,675)$ secara parsial variabel promosi jabatan berpengaruh positif dan signifikan terhadap kinerja karyawan PT. Perkebunan Nusantara III Labuhan Haji Kabupaten Labuhanbatu Utara.

\section{Hasil Uji Simultan (Uji F)}

Uji Simultan (Uji F) dilakukan untuk menguji secara serempak apakah budaya kerja dan promosi jabatan berpengaruh terhadap peningkatan kinerja karyawan PT. Perkebunan Nusantara III Labuhan Haji Kabupaten Labuhanbatu Utara, dapat dilihat pada Tabel 3 berikut :

\section{Tabel 3}

\section{Hasil Uji Serempak (Uji F)}

Tabel 3, menunjukkan hasil uji-F untuk koefisien korelasi persamaan regresi diperoleh nilai F hitung sebesar 50.119 dengan tingkat signifikan sebesar 0.000. Nilai $F$ tabel dicari pada tabel $F$ dengan $\mathrm{df}_{1}=2$ dan $\mathrm{df} 2=47$ sehingga diperoleh nilai $\mathrm{F}$ tabel sebesar 3,20 dengan hasil tersebut dimana $\mathrm{F}$ hitung $>\mathrm{F}$ tabel dan nilai signifikan yang ANOVA $^{\mathrm{a}}$

\begin{tabular}{|c|c|c|c|c|c|}
\hline Model & $\begin{array}{l}\text { Sum of } \\
\text { Squares }\end{array}$ & Df & $\begin{array}{c}\text { Mean } \\
\text { Square }\end{array}$ & $\mathrm{F}$ & Sig. \\
\hline \multirow[b]{3}{*}{ Total } & 36.232 & 2 & 18.116 & 50.119 & $.000^{\mathrm{b}}$ \\
\hline & 16.988 & 47 & .361 & & \\
\hline & 53.220 & 49 & & & \\
\hline
\end{tabular}

a. Dependent Variable: Kinerja Karyawan

b. Predictors: (Constant), Promosi Jabatan, Budaya Kerja lebih kecil dari pada alpha 5\% maka kesimpulan yang dapat diambil adalah signifikan secara statisik. Hipotesis Ha diterima karena $\mathrm{F}$ hitung $>\mathrm{F}$ tabel

Coefficients $^{\mathrm{a}}$

\begin{tabular}{|c|c|c|c|c|c|}
\hline \multirow[t]{2}{*}{ Model } & \multicolumn{2}{|c|}{$\begin{array}{l}\text { Unstandardized } \\
\text { Coefficients }\end{array}$} & \multirow{2}{*}{\begin{tabular}{|c|}
$\begin{array}{c}\text { Standard } \\
\text { ized } \\
\text { Coeffici } \\
\text { ents }\end{array}$ \\
Beta \\
\end{tabular}} & \multirow[t]{2}{*}{$\mathrm{T}$} & \multirow[t]{2}{*}{ Sig. } \\
\hline & $\mathrm{B}$ & Std. Error & & & \\
\hline \multirow{3}{*}{$\begin{array}{l}\text { (Constant) } \\
\text { Budaya Ke } \\
\text { Promosi } \\
\text { Jabatan }\end{array}$} & 2.505 & 1.873 & & 1.337 & .188 \\
\hline & .764 & .081 & .792 & 9.465 & .000 \\
\hline & .112 & .071 & .132 & 2.583 & .002 \\
\hline
\end{tabular}

a. Dependent Variable: Kinerja Karyawan
$(50.119>3,20)$ dan signifikan $\mathrm{F}<$ alpha $5 \%$ $(0,000<0,05)$ yang berarti bahwa secara bersamasama terdapat pengaruh signifikan antara budaya kerja dan promosi jabatan terhadap peningkatan kinerja karyawan PT. Perkebunan Nusantara III Labuhan Haji Kabupaten Labuhanbatu Utara.

\section{Uji Koefesien Determinasi $\left(\mathbf{R}^{\mathbf{2}}\right)$}

Hasil pengujian koefisien determinasi dapat dilihat dari Tabel 4 sebagai berikut :

Tabel 4

Hasil Koefisien Determinasi $\left(\mathbf{R}^{\mathbf{2}}\right)$ 
Model Summary

\begin{tabular}{l|r|r|r|c|}
\hline $\begin{array}{l}\text { Mode } \\
1\end{array}$ & $\mathrm{R}$ & $\begin{array}{c}\mathrm{R} \\
\text { Square }\end{array}$ & $\begin{array}{c}\text { Adjusted } \\
\mathrm{R} \text { Square }\end{array}$ & $\begin{array}{c}\text { Std. Error of the } \\
\text { Estimate }\end{array}$ \\
\hline 1 & $.825^{\mathrm{a}}$ & .681 & .667 & .60121 \\
\hline
\end{tabular}
a. Predictors: (Constant), Promosi Jabatan, Budaya Kerja
b. Dependent Variable: Kinerja Karyawan

Tabel 4, menunjukkan bahwa Nilai $R$ sebesar 0,825 berarti hubungan antara budaya kerja, promosi jabatan terhadap peningkatan kinerja karyawan sebesar 82,5\% menandakan hubungannya cukup kuat. Sedangkan nilai Asjusted $R$ Square sebesar 0,667 berarti bahwa peningkatan kinerja karyawan dapat di jelaskan oleh budaya kerja, promosi jabatan sebesar $66,7 \%$. Sedangkan sisanya $33,3 \%$ dapat di jelaskan oleh variabel lain yang tidak diteliti dalam penelitian ini.

\section{PEMBAHASAN}

\section{Secara Parsial Budaya Kerja Berpengaruh Positif dan Signifikan Pada Peningkatan Kinerja Karyawan.}

Dari hasil Uji T menunjukkan bahwa budaya kerja secara parsial berpengaruh positif dan signifikan terhadap peningkatan kinerja karyawan di PT. Perkebunan Nusantara III Labuhan Haji, berdasarkan kriteria nilai $t_{\text {hitung }}(9,465)>t_{\text {tabel }}(1,675)$ dengan nilai signifikan $0,000<0,05$. Oleh karena demikian hipotesis diterima.

\section{Secara Parsial Promosi Jabatan Berpengaruh Positif dan Signifikan Pada Peningkatan Kinerja Karyawan}

Dari hasil Uji T menunjukkan bahwa promosi jabatan secara parsial berpengaruh positif dan signifikan terhadap peningkatan kinerja karyawan di PT. Perkebunan Nusantara III Labuhan Haji, berdasarkan kriteria nilai $t_{\text {hitung }}(2,583)>t_{\text {tabel }}(1,675)$ dengan nilai signifikan $0,002<0,05$. Oleh karena demikian hipotesis diterima.

\section{Secara Simultan Budaya Kerja dan Promosi Jabatan Berpengaruh Positif dan Signifikan Terhadap Peningkatan Kinerja Karyawan.}

Dari hasil Uji F menunjukkan bahwa Budaya Kerja dan Promosi Jabatan secara simultan (serempak) berpengaruh terhadap Peningkatan Kinerja Karyawan bedasarkan kriteria nilai $F_{\text {hitung }}$ sebesar 50.119 dengan nilai signifikan $0,000^{\mathrm{a}}$. maka $\mathrm{F}_{\text {hitung }}(50.119)>\mathrm{F}_{\text {tabel }}(3,20)$ dengan signifikasi $0,000^{\mathrm{a}}<0,05$.

Maka berdasarkan hasil tersebut dapat disimpulkan bahwa budaya kerja dan promosi jabatan secara simultan berpengaruh positif dan signifikan terhadap peningkatan kinerja karyawan yang berarti bahwa semakin baik budaya kerja dan semakin meningkat dan merata promosi jabatan, maka menghasilkan peningkatan kinerja karyawan. Dengan demikian hipotesis diterima.

\section{KESIMPULAN DAN SARAN}

\section{Kesimpulan}

Dari hasil penelitian yang telah dilakukan, penulis mengambil beberapa kesimpulan sebagai berikut :

1. Budaya Kerja berpengaruh positif dan signifikan terhadap Peningkatan Kinerja Karyawan pada PT. Perkebunan Nusantara III Labuhan Haji sesuai hasil uji $t$ dimana nilai $t_{\text {hitung }}(9,465)>t_{\text {tabel }}$ $(1,675)$ dengan nilai signifikan $0,000<0,05$.

2. Promosi Jabatan berpengaruh positif dan signifikan terhadap Peningkatan Kinerja Karyawan pada PT. Perkebunan Nusantara III Labuhan Haji sesuai hasil uji t dimana nilai $t_{\text {hitung }}(2,583)>$ $\mathrm{t}_{\text {tabel }}(1,675)$ dengan nilai signifikan $0,002<0,05$. 
3. Budaya Kerja dan Promosi Jabatan berpengaruh positif dan signifikan terhadap Peningkatan Kinerja Karyawan (Y) pada PT. Perkebunan Nusantara III Labuhan Haji, berdasarkan hasil Uji $\mathrm{F}$ dimana $\mathrm{F}_{\text {hitung }}(50.119)>\mathrm{F}_{\text {tabel }}(3,20)$ dengan signifikasi $0,000^{\text {an }}<0,05$.

4. Nilai $R$ sebesar 0,825 yang berarti hubungan antara budaya kerja, promosi jabatan terhadap peningkatan kinerja karyawan sebesar $82,5 \%$, membuktikan hubungannya cukup kuat. Sedangkan nilai Asjusted $R$ Square sebesar 0,667 yang berarti bahwa peningkatan kinerja karyawan dapat di jelaskan oleh budaya kerja, promosi jabatan sebesar 66,7\%. Sedangkan sisanya 33,3\% dapat di jelaskan oleh variabel lain yang tidak diteliti.

\section{Saran}

Berdasarkan hasil yang didapat, penulis memberikan saran sebagai berikut :

1. Karena budaya kerja salah satu variabel yang sangat mempengaruhi peningkatan kinerja karyawan, maka sebaiknya pemimpin perusahaan selalu menghimbau dan memotivasi karyawan agar tetap mematuhi dan melaksanakannya serta adanya konsekuensi kepada karyawan bagi yang betul-betul mematuhi dengan pemberian reward dan bagi yang tidak mematuhi maka akan dikenakan sanksi atau punishment.

2. Karena promosi jabatan merupakan salah satu variabel yang berpengaruh dalam meningkatkan kinerja karyawan, maka sebaiknya pimpinan perusahaan menetapkan promosi jabatan secara berkala dan konsisten dengan berpedoman pada indikator penilaian mendapatkan promosi jabatan. Hal ini berguna untuk memotivasi dan menyemangati karyawan.

3. Baiknya pemimpin memperhatikan keadilan dan pemerataan dalam promosi jabatan yang disesuaikan dengan aturan yang berlaku serta menghindari sikap diskriminasi atau like or dislike..

\section{DAFTAR PUSTAKA}

\section{Alwi, Syafarudin. 2015. Manajemen Sumber Daya Manusia, Strategi Keunggulan}

Kompetitif. Yogyakarta: BPFE .

Arep dan Tanjung, (2010), Manajemen Sumber Daya Manusia, Universitas Trisakti, Jakarta.

Davis, Keith dan Newstrom Shon W, 2012. Perilaku Dalam Organisasi. Edisi Ketujuh, Penerbit Erlangga, Jakarta.

Gomes, Cardaso dan Faustino, 2012. Manajemen Sumber Daya Manusia. Yogyakarta: Andi

Hasibuan, Malayu S.P. 2012. Manajemen Sumber Daya Manusia, Edisi Revisi. Jakarta: Bumi Aksara

Handoko, T. Hani. 2014. Manajemen Personalia dan Sumber Daya Manusia. Edisi kedua, BPFE, Yogyakarta.

Malthis, Robert L dan John H. Jackson. 2015. Manajemen Sumber Daya Manusia, Buku I. Salemba Empat, Jakarta

Sinaga, Mangarissan. 2013. Analisis Pengaruh Budaya kerja dan Reward Terhadap Kinerja pegawai Pada PT. Soelong Laoet Medan. Sekolah Pasca Sarjana USU. (tidak dipublikasikan). 
Sudarmadi. 2013. Analisis Pengaruh Budaya kerja dan Gaya Kepemimpinan Terhadap Kepuasan Kerja dan Kinerja pegawai (Studi Empiris: Pegawai Administratif Universitas Semarang). Program Pasca Sarjana UNDIP. (tidak dipublikasikan).

Tjitra, H., 2013. Mencapai Sukses Permanen Melalui Budaya kerja, di dalam buku Corporate Culture, Challenge to Excellence, editor: Moeljono, D., Jakarta: PT Elex Media Komputindo.

Wibowo, F. Dewi. 2012. Analisis Pengaruh Peran Kepemimpinan dan Pengembangan Karir Terhadap Komitmen Organisasi Dalam Meningkatkan Kinerja pegawai (Studi Kasus: PT. Bank Maspion Indonesia Cabang Semarang). Program Pasca Sarjana UNDIP. (Tidak dipublikasikan). 